\title{
Analysis of Human Resource Needs Through the Workload of PT Telkom Indonesia (Case Study: Government Service Division)
}

\author{
Helmi Alfiansyah $^{1}$, M. Syamsul Maarif ${ }^{2}$, Nimmi Zulbainarni $^{3}$ \\ ${ }^{1,2,3}$ School of Business, IPB University, Jl. Raya Padjajaran Bogor, Indonesia \\ Corresponding Author: Helmi Alfiansyah
}

\begin{abstract}
Human resource planning is a series of activities carried out to anticipate business and environmental demands on the organization in the future and to meet labor needs that arise from certain conditions. This study aims to analyze the use of working time by employees in the Government Service Division; analyze the optimal number of employees based on the workload in the Government Service Division, and analyze the alternatives or managerial implications that can be offered to the Government Service Division.

This study used the Workload Indicator Staffing Need (WISN) analysis method with work sampling technique. The population in this study are employees who work in the Government Service Division (DGS). The sample size was selected using the probability sampling method and the sample was taken using a purposive sampling technique.

The results showed that the highest use of working time was found in the Legal 1 Bidding and Management sub-unit with a value of $84.32 \%$ and the lowest was found in the Complaint Handling Assurance and Delivery sub-unit with a value of $80 \%$. Each Government Service Division unit requires additional employees, with the highest need being in the Assurance and Delivery unit as many as 19 people and the lowest need being in the Government Solution and Partnership unit as many as eight people. The managerial implication that can be given as input is that the company needs to re-evaluate the planning of all aspects both in recruitment, competence, and the development that will be carried out.
\end{abstract}

Keywords: employee needs, WISN, workload, work sampling

\section{INTRODUCTION}

Economic growth and the rapid development of information technology have the impact of intense business competition and occur in all economic sectors. The business world that is influenced by the competitive environment is required to adapt to market demands that require a fast and flexible response in improving service to customers. For this reason, a structural change in business management requires changes to become more effective, efficient, and productive.

PT Telkom Indonesia is the only company in the form of a State-Owned Enterprise (BUMN) which is engaged in telecommunications services. Along with the increasing needs of the community and government, the level of competition felt by PT. Telkom Indonesia. This is due to the emergence of private companies engaged in telecommunications services, such as Indosat, XL Axiata, Smartfen, and Ericsson. In addition to the high level of competition in achieving company goals, the level of competition in obtaining quality human resources has also increased. With the increasing business competition in the telecommunications sector, PT Telkom Indonesia must strive to maintain its position as a market leader.

In the era of globalization, companies are no longer focused on 
investing assets in buildings, offices, or other investments. Companies invest their assets in human resource development and provide adequate facilities to support employee performance. Companies are starting to realize that the workforce has a significant impact on the progress of the company, in accordance with Notoadmojo (2009) that human resource management is not the ultimate goal of a process, but a set of tools to achieve a company goal. In addition, the evaluation of human resources must be carried out due to the shift in lifestyle to work within the flexibility of working hours and work places.

Workloads that are not in accordance with the capacity of human resources will have an impact on work effectiveness and efficiency. The workload given to employees consists of three categories, namely workload according to standards, workload that is too high, and workload that is too low. A workload that is too low will result in an excess of manpower, while a workload that is too high will result in a shortage of manpower. Lack of manpower makes it difficult for the workforce to achieve the targets set by the company, while excess labor results in cost inefficiency for the company. The balance between workload and human resource needs is an absolute thing to be realized, so that work effectiveness and efficiency can be achieved. Therefore,

Along with the shift towards digitalization, there are more and more demands from companies where these demands must be followed by the right quality of human resources. High competition demands improvements to the scope of work such as cost efficiency, increasing employee productivity, and doing work in accordance with the regulations set by the company. Basically the life of the company is run by employees who work according to their position. The company's future is determined by employees who are the company's main assets.

Manpower planning is an important thing to pay attention to, because every company has human resources that vary from one another, so proper handling is needed. Manpower planning can be started by analyzing the work and workload of each human resource. An uneven workload can result in an unfavorable work atmosphere because employees feel that the workload given is too excessive or even insufficient.

The Government Service Division (DGS) is one of the business units in the Directorate of Enterprise \& Business Service (Directorate of EBS). Regarding the workload, most of the units in DGS have not received the right composition of employees at work. This causes most units to often work outside of operational hours and even work outside of working days. Therefore, the number of employees at DGS has not carried out proper HR planning.

Inefficiency is one of the focuses of attention in DGS. DGS is a division that addresses all telecommunications needs in the government sector. For the past five years, DGS has been the division that has the largest contribution in achieving the enterprise \& business service Directorate's revenue target. As the best division under the EBS Directorate, DGS has a revenue target that increases every year. With the increase in revenue targets each year, the workload and HR needs also increase.

DGS has an important role in PT Telkom Indonesia. This is because DGS is tasked with meeting all telecommunication needs of government institutions, both in the urban village sector to heads of state. In this regard, DGS is expected to be able to provide the best performance by providing a balance between workload and human resource needs.

Based on the description above, several problems can be formulated, namely as follows:

1. How do employees of the Government Service Division (DGS) use their working time?

2. What is the optimal number of Government Service Division (DGS) employees based on employee workload? 
3. What are the alternatives or managerial implications that can be offered to the Government Service Division (DGS)?

\section{LITERATURE REVIEW \\ Human Resource Management}

Hasibuan (2001) states that human resources are all humans who are involved in an organization in seeking the realization of organizational goals. If the organization is defined as an economic enterprise, then human resources are defined as all the people involved, including those who work to achieve company goals. Handoko (2001) states that human resource planning is a series of activities carried out to anticipate future business and environmental demands on the organization and to meet the workforce needs arising from these conditions.

Planning is said to be a process for deciding the goals to be achieved over a period of time to come and what will be done to achieve these goals, so planning must precede all management activities so that the organization can be successful in achieving its goals. With human resource planning, selection, training and development activities as well as other activities related to human resources will be more focused. Human resource planning is processed by planners and the results become plans. In a plan, objectives and implementation guidelines are set as well as the basis for control. Without a plan, control cannot be implemented and without control the implementation of a good or wrong plan cannot be known (Hasibuan 2005).

\section{Human Resource Planning}

Human resource planning is a decision-making process in hiring and placing staff in the company (Mangkuprawira 2003). One of the classic definitions of planning is that planning is basically a decision making now about things that will be carried out in the future. HR planning thus focuses attention on certain steps taken by management to ensure the availability of the right human resources to occupy the right positions, positions and jobs at the right time. This is done in order to achieve the goals and various targets that have been and will be set (Rivai and Sagala 2009).

According to Rivai (2006), there are several advantages for large companies that use HR planning, namely:

1. Strategic integration between demand and the number of existing staff.

2. Utilization of available human resources effectively.

3. HR competition and future company goals effectively.

4. Economically efficient in hiring new employees.

5. Expand HR information in accordance with HR activities and other organizational units.

6. The large demand in the local labor market will be met.

7. Coordination of HR programs and available needs

\section{Human Resource Needs}

A more precise determination of the number of workers can be done by adding the number of workers who have been calculated with a certain percentage or percentage of allowances. This percentage shows the amount of allowance that can be received due to employee absence due to illness, death, and other reasons. Another method that can be used to calculate manpower needs is through calculating employee needs based on workload as contained in the Decree of the Minister of Administrative Reform Number: KEP/75/M.PAN/7/2004 concerning Guidelines for Calculation of Employee Needs based on Workload in the framework of Preparation of Formation of Civil Servants. Calculations can be carried out using the general method, namely the calculation for general functional positions and certain functional positions whose requirements have not been determined by the supervisory agency. The number of employee needs is calculated by identifying the workload through several approaches, 
namely work results, work objects, work equipment, tasks per job assignment.

\section{Workload}

HR needs can be calculated by identifying how much the company's output in a particular division wants to achieve. Then it is translated in the form of the length (hours and days) of employees needed to achieve the output, so that it can be seen in what types of work there is a negative deviation or according to the standard. Workload analysis is closely related to fluctuations in market demand for company goods and services as well as the fulfillment of the human resources needed to meet commodity market demand. The higher the market demand for certain commodities, the company will immediately fulfill it by increasing its production. In line with that, the number of workers needed is increasing (Mangkuprawira 2003).

The workload is calculated in hours. Workload is also a number of work targets or target results that must be achieved in an average employee. By using workload measurement, it can be easier to determine the number of employees. Workload analysis is the determination of the number of workers needed to complete a job within a certain period of time (Hasibuan 2005). Workload can also refer to the total energy output of a system, especially from someone who performs or performs a dedicated task from time to time. Workload Analysis is a management technique that is carried out systematically to obtain information about the level of efficiency and effectiveness of the organization's work based on the volume of work.

\section{Job Analysis}

Job analysis is the procedure followed to determine the responsibilities of positions and the characteristics of the people working for those positions (Dessler 2004). Some of the terminology about job analysis, one of which is that job analysis is an activity or process of collecting and compiling various information relating to each job, task, type of work, and operational responsibilities to realize organizational or business goals of a company (Rivai, 2006).

\section{METHODS}

The research was conducted at the Government Service Division (DGS) of PT. Telkom Indonesia. The research location is located at Menara Multimedia Building, Kebon Sirih Street No. 12, Central Jakarta. The research was conducted from March to April 2020. The data used in this study are quantitative and qualitative data. Quantitative data consists of the number of working time usage, effective working time, average completion time of a main task (average ability standard) and quantity or main task load for a year, while qualitative data consists of information about the main tasks of the employee's work. .

The data sources come from primary data and secondary data. Primary data is obtained directly through observation of activities carried out by employees during working hours and the results of interviews. Secondary data was obtained from the Government Service Division's Human Resource Management data (HRM DGS) regarding workloads and those related to workloads.

The population in this study are employees who work in the Government Service Division (DGS). The sample size was selected using the probability sampling method where every employee has the same opportunity to become the research sample. The sampling method is purposive sampling where the sample is taken based on the availability and ease of obtaining it.

Primary data collection method regarding employees is obtained through the Workload Indicator Staff Need (WISN) method with a work sampling approach, namely the completion and recording of activities carried out by employees during working hours, with an observation time interval of every ten minutes. The activities observed in the study using work sampling are grouped according to the categories of 
productive, unproductive, and personal activities (Ilyas, 2011).

The method of calculating labor requirements used is the Workload Indicator Staff Need (WISN). WISN is a method of calculating HR needs based on workload by observing the real work carried out by each category of HR in each work unit in a workplace. The steps for calculating labor requirements based on WISN (WHO 2010) consist of five steps, namely:

\section{1) Set working time}

Determination of working time aims to obtain the available working time in each category of HR working in the company for one year. The calculation for setting working time is determined by the following formula:

Working Time $=[\mathrm{A}-(\mathrm{B}+\mathrm{C}+\mathrm{D}+\mathrm{E})] \mathrm{x} \mathrm{F}$

Information:

$\mathrm{A}=$ Weekdays $\quad \mathrm{D}=$ National Holiday

$\mathrm{B}=$ Annual Leave $\mathrm{E}=$ Absence from work

$\mathrm{C}=$ Training $\quad \mathrm{F}=$ Working Time

\section{2) Define HR work units and categories}

Determining work units and categories of HR aims to obtain work units and categories of HR who are responsible for carrying out activities both inside and outside the workplace.

\section{3) Setting workload standards}

The standard workload is the volume or quantity of workload for one year per HR category. The standard workload for a main activity is prepared based on the time required to complete the work and the time available per year for each category of workforce. The standard workload calculation formula is as follows:

Workload standard $=\frac{\text { Working time available }}{\text { Main activity average }}$

\section{4) Setting the standard of allowance}

The purpose of compiling the allowance standard is to obtain an allowance factor for each category of HR including the type of activity and the time needed to complete an activity that is not directly related or influenced by the high and low quality or number of main activities or services. Standard Allowance can be determined by performing calculations based on the following formula:

Allowance standard $=\frac{\text { Factor time per allowance }}{\text { Working time available }}$

\section{5) Calculation of manpower requirements per work unit}

The activity data that have been obtained and the Workload Standards and Allowance Standards are data sources for calculating HR needs in each installation and work unit using the following formula:

$$
\text { HR needs }=\frac{\text { Total product service }}{\text { Workload standard }}+\text { Allowance standard }
$$

Based on the calculation formula, the HR requirements for each main activity are first added up before being added to the Allowance Standards for each HR category.

\section{RESULT AND DISCUSSION Employee Workload}

Based on the results of the study, it was found that there were a lot of job descriptions carried out by employees and needed optimal energy to get the work expected by the company. The job descriptions have different implementation times and SOPs and sometimes the time given is not enough or does not match the time set.

\section{Working Time Usage}

Observations on the use of working time in the Government Service Division are carried out during working hours, namely from 08.00 to 17.00 WIB. Direct observations were carried out by researchers by recording all activities that respondents did from beginning to end. The observed activities consist of productive activities, unproductive activities, and personal activities. Observations on the use of working time in the Business Plan sub-unit show that the time distribution of the 
Business Plan sub-unit with the highest percentage is productive activities, especially for actuating activities which have a time distribution of $50.04 \%$. The distribution of time with the lowest percentage is productive activities, especially for actuating activities which have a time distribution of $1.45 \%$.

The results of observations of the use of working time show that the distribution of time in the Account Data Management sub-unit with the highest percentage is productive activities, especially for actuating activities which have a time distribution of $42.46 \%$. The distribution of time with the lowest percentage is productive activities, especially for planning activities which have a time distribution of $2.11 \%$.

Observations on the use of working time show that the time distribution of the Secretariate and Resource Optimization subunit with the highest percentage is productive activities, especially for actuating activities which have a time distribution of $19.88 \%$. The distribution of time with the lowest percentage is personal activity which has a time distribution of 3.04\%.

The results of observations of the use of working time show that the time distribution of the Revenue Assurance and Quality Management sub-unit with the highest percentage is productive activities, especially for actuating activities which have a time distribution of $23.97 \%$. The distribution of time with the lowest percentage is non-productive activities which have a time distribution of $1.92 \%$.

Observations on the use of working time show that the time distribution of the Invoicing and Cash Collection sub-units with the highest percentage is productive activities, especially for actuating activities which have a time distribution of $9.31 \%$. The distribution of time with the lowest percentage is productive activities, especially for planning activities which have a time distribution of $1.07 \%$.
The results of observations on the use of working time show that the time distribution of the Legal Compliance 1 subunit and the time distribution of the Legal Compliance 2 sub-unit shows the highest percentage, namely productive activities, especially for actuating activities which have a time distribution of $15.76 \%$. The distribution of time with the lowest percentage is productive activities, especially for organizing activities which have a time distribution of $1.13 \%$.

Observations on the use of working time show that the time distribution of the Outbound Logistics sub-unit with the highest percentage is productive activities, especially for actuating activities which have a time distribution of $17.27 \%$. The distribution of time with the lowest percentage is productive activities, especially for planning activities which have a time distribution of $1.18 \%$.

The results of observations of the use of working time show that the time distribution of the Inbound Logistics subunit with the highest percentage is productive activities, especially for actuating activities which have a time distribution of $12.53 \%$. The distribution of time with the lowest percentage is productive activities, especially for planning activities which have a time distribution of $1.49 \%$.

Observations on the use of working time show that the time distribution of the Bidding Administration Support sub-unit with the highest percentage is productive activities, especially for actuating activities which have a time distribution of $25.09 \%$. The distribution of time with the lowest percentage is productive activities, especially for planning activities which have a time distribution of $2.11 \%$.

Observations on the use of working time show that the time distribution of the Wifi Deployment and Service Migration sub-unit with the highest percentage is productive activity, especially for actuating activities which have a time distribution of $18.78 \%$. The distribution of time with the 
lowest percentage is productive activities, especially for planning activities which have a time distribution of $1.07 \%$.

Observations on the use of working time show that the time distribution of the Reconciliation and Performance Report subunit with the highest percentage is productive activity, especially for actuating activities which have a time distribution of $20.86 \%$. The distribution of time with the lowest percentage is productive activities, especially for planning activities which have a time distribution of $1.59 \%$.

Observations on the use of working time show that the time distribution of the Order Connectivity Management sub-unit with the highest percentage is productive activities, especially for actuating activities which have a time distribution of $16.56 \%$. The distribution of time with the lowest percentage is productive activities, especially for planning activities which have a time distribution of $1.59 \%$.

The results of observations on the use of working time show that the time distribution of the VVIP and Event Management Service sub-units with the highest percentage is productive activities, especially for organizing activities which have a time distribution of $8.72 \%$. The distribution of time with the lowest percentage is productive activities, especially for planning activities which have a time distribution of $1.05 \%$.

The results of observations on the use of working time show that the time distribution of the Complaint Handling sub-unit with the highest percentage is productive activities, especially for actuating activities which have a time distribution of $18.82 \%$. The distribution of time with the lowest percentage is productive activities, especially for planning activities which have a time distribution of $1.47 \%$.

Observations on the use of working time show that the time distribution of the Solution Deployment sub-unit with the highest percentage is productive activity, especially for actuating activities which have a time distribution of $20.53 \%$. The distribution of time with the lowest percentage is productive activities, especially for planning activities which have a time distribution of $1.74 \%$.

The results of observations on the use of working time show that the time distribution of the Solution Deployment and Capex sub-units with the highest percentage is productive activities, especially for actuating activities which have a time distribution of $23.05 \%$. The distribution of time with the lowest percentage is productive activities, especially for planning activities which have a time distribution of $1.28 \%$.

The results of observations on the use of working time show that the distribution of time for the Government Relations Support sub-unit with the highest percentage is productive activities, especially for actuating activities which have a time distribution of $12.68 \%$. The distribution of time with the lowest percentage is productive activities, especially for planning activities which have a time distribution of $1.53 \%$.

The results of observations on the use of working time show that the time distribution of the Account Team Management sub-unit with the highest percentage is productive activities, especially for controlling activities which have a time distribution of $9.50 \%$. The distribution of time with the lowest percentage is productive activities, especially for planning activities which have a time distribution of $2.11 \%$.

Observations on the use of working time show that the time distribution of the Government Development Program subunits with the highest percentage is productive activities, especially for actuating activities which have a time distribution of $12.52 \%$. The distribution of time with the lowest percentage is productive activities, especially for planning activities which have a time distribution of $2.24 \%$.

The results of observations on the use of working time show that the 
distribution of time for the Smart City Experience sub-unit with the highest percentage is productive activities, especially for actuating activities which have a time distribution of $12.53 \%$. The distribution of time with the lowest percentage is productive activities, especially for planning activities which have a time distribution of $2.29 \%$.

The results of observations of the use of working time show that the distribution of time for the Smart City Solution Integration sub-unit with the highest percentage is productive activities, especially for actuating activities which have a time distribution of $18.89 \%$. The distribution of time with the lowest percentage is productive activities, especially for planning activities which have a time distribution of $3.16 \%$.

The results of observations of the use of working time show that the distribution of time for the Smart City Planning and Controlling sub-unit with the highest percentage is productive activities, especially for actuating activities which have a time distribution of $18.89 \%$. The distribution of time with the lowest percentage is productive activities, especially for planning activities which have a time distribution of $2.11 \%$.

\section{Input Analysis}

Based on the Minister of Health Regulation No. 971/MENKES/PER/XI/ 2009 it is explained that in every health structural position it must be equipped with competency standards that can assist employees in overcoming work problems. The suitability of the workload can be analyzed by type of workforce, it can also be associated with age, education, gender and other variables, depending on the objectives and needs of research and management (Nazmin et al. 2013; Shivam et al. 2014; Tibby et al. 2004). According to Hasibuan (2006) revealed that the quality and quantity of employees must be in accordance with the needs of the company, so that they are effective and efficient in supporting the achievement of goals. Based on the above theories, employee characteristics (age, gender, education, and years of service) are related to the placement of employees in certain positions.

Based on the results of interviews with respondents for the category of division of job descriptions, respondents said that the distribution was quite good because each employee was given a workload that was in accordance with his educational background. However, there are several obstacles faced by some respondents in terms of completing the work. These constraints include the lack of facilities and infrastructure for the work environment, the high intensity of innovation in technology, and the movement of physical documents.

The foundation for establishing the organizational structure of the Government Service Division is the eTOM (Enhance Telkom Organization Map) which was adopted from the ITU (International Telecommunication Union). The workload in each sub-unit has met the needs of telecommunication companies if all structural organizational formations have been met. However, the Government Service Division still has a staffing index which is still far below the expectation index, so there are still many structural positions that have not been filled by workers. The barriers that have been identified include:

1. Lack of manpower, where the government Service Division's staffing index is at $66 \%$. However, to recruit workers, you must submit an application to the Directorate of Human Capital Management.

2. The workload is quite high in several sub-units of the Government Service Division.

3. The labor recruitment process takes a long time, because prospective workers carry out a series of training for one year.

The interviews also identified several efforts that have been made to overcome these obstacles, namely: 
1. Carry out the recruitment of professional hired workers. Professional workers are hired to be one solution because the recruitment process is fast. In addition, professional recruitment is a welltargeted solution so that workers are placed in positions that match their expertise.

2. Establish an account management team sub-unit, which is a sub-unit that supports team development, so that the Government Service Division can adjust its performance with the development of company achievements which always increase every year.

From the results of in-depth interviews, it was found that the problem of shortage or excess of manpower is a top priority to be addressed immediately. In addition to quantity, the quality of work also affects the workload. It can be seen that there is still a lack of workforce in the Government Service Division. In addition, the account management team sub-unit is expected to continue to develop other subunits, so that the workforce can make an optimal contribution. Regular training and education can help employees improve their quality and competence so that work results can be achieved optimally (Brown et al. 2011; Castro and Stetz 2007; Durham et al. 2007).

In addition, what should also be done in this perspective is the recruitment process to provide quality additional personnel that can increase labor productivity (Pregiwati 2007). If the recruitment process is not successful in getting quality employees, then managers should provide more training to employees because the progress of a company depends on the quality of the workforce (Cascio 2007, Musau et al. 2008). Rahardjo (2008) said that the implementation of quality training programs and recruitment processes for employees will increase employee productivity every year.

\section{Process Analysis}

In this study, the work sampling method was only used to calculate the time used by employees during working hours. Furthermore, by getting the amount of productive, unproductive, and personal working time, employees will be able to calculate the optimal power requirement based on the WISN calculation formula.

\section{Employee Needs}

After conducting research in the field using a work sampling form and interviews in the form of a questionnaire which became a source of information in this study, then with the steps written in the WISN user manual (WHO 2010) the results of the calculation of the number of human resources in the Government Service division of PT Telkom Indonesia as follows:

\section{1) Working Timing Available}

Based on the results of the study, the determination of working time in the Government Service division of PT Telkom Indonesia can be seen in Table 1 .

\begin{tabular}{|l|l|l|l|}
\multicolumn{4}{|c}{ Table 1 Determination of Working Time } \\
\hline Code & Factor & Amount & Information \\
\hline A & Working days & 261 & Per year \\
\hline B & Annual leave & 12 & Per year \\
\hline C & Training & 10 & Per year \\
\hline D & National holiday & 14 & Per year \\
\hline E & Absence from work & 3 & Per year \\
\hline F & Working time & 8 & Per year \\
\hline Working Time Available & 1,776 & \\
\hline Available Working Days & 222 & \\
\hline Working Minutes Available & 106,560 & \\
\hline
\end{tabular}

\section{2) Determination of work units}

In this study, the work units designated as research objects are all subunits in the Government Service Division with a portion of one person for each subunit.

\section{3) Preparation of workload standards}

The standard workload is the volume per workload quantity for one year per HR category. The standard workload for a main activity is prepared based on the time required to complete it (average time) and the time available per year for each category of workforce. The next step is to make it easier to determine the workload of each category of HR, it is necessary to arrange the main activities and service activities, 
Helmi Alfiansyah et.al. Analysis of human resource needs through the workload of PT Telkom Indonesia (case study: government service division).

which are directly related to indirect. The results of the calculation of the standard workload of each sub unit based on the main activities obtained by calculating the available working time can be seen in Table 2.

Table 2. Preparation of workload standards

\begin{tabular}{|c|c|c|c|c|}
\hline No & Category & Activity & Average Time (Minutes) & Standard Workload \\
\hline \multicolumn{5}{|c|}{ PPS } \\
\hline 1 & Business Plan & $\begin{array}{l}\text { Planning } \\
\text { Organizing } \\
\text { Actuating } \\
\text { controlling } \\
\end{array}$ & $\begin{array}{l}8.50 \\
57.99 \\
274.70 \\
57.32 \\
\end{array}$ & $\begin{array}{l}12,536.47 \\
1,837.56 \\
387.91 \\
1,859.04 \\
\end{array}$ \\
\hline 2 & Data Management & $\begin{array}{l}\text { Planning } \\
\text { Organizing } \\
\text { Actuating } \\
\text { controlling } \\
\end{array}$ & $\begin{array}{l}10,15 \\
25.45 \\
299.33 \\
60,20 \\
\end{array}$ & $\begin{array}{l}10,498.52 \\
4,187.03 \\
356.00 \\
1,770.10 \\
\end{array}$ \\
\hline 3 & Secretarial and Resource Optimization & $\begin{array}{l}\text { Planning } \\
\text { Organizing } \\
\text { Actuating } \\
\text { controlling }\end{array}$ & $\begin{array}{l}15.87 \\
18.71 \\
315,70 \\
37,20 \\
\end{array}$ & $\begin{array}{l}6,714.56 \\
5,695.35 \\
337.54 \\
2,864.52 \\
\end{array}$ \\
\hline 4 & Revas & $\begin{array}{l}\text { Planning } \\
\text { Organizing } \\
\text { Actuating } \\
\text { controlling } \\
\end{array}$ & $\begin{array}{l}15.58 \\
26.01 \\
306.59 \\
53.13 \\
\end{array}$ & $\begin{array}{l}6,839.54 \\
4096.89 \\
347.57 \\
2005.65 \\
\end{array}$ \\
\hline 5 & Invoicing & $\begin{array}{l}\text { Planning } \\
\text { Organizing } \\
\text { Actuating } \\
\text { controlling } \\
\end{array}$ & $\begin{array}{l}5.15 \\
36,80 \\
300.64 \\
45.98 \\
\end{array}$ & $\begin{array}{l}20,691.26 \\
2,895.65 \\
354.44 \\
2,317.53 \\
\end{array}$ \\
\hline \multicolumn{4}{|c|}{ Amount } & $88,593.11$ \\
\hline \multicolumn{5}{|c|}{ BDM } \\
\hline 1 & Legal 1 & $\begin{array}{l}\text { Planning } \\
\text { Organizing } \\
\text { Actuating } \\
\text { controlling } \\
\end{array}$ & $\begin{array}{l}5.65 \\
20.56 \\
336.62 \\
41.41 \\
\end{array}$ & $\begin{array}{l}18,860,18 \\
5.182 .88 \\
316.56 \\
2,573.29 \\
\end{array}$ \\
\hline 2 & Legal 2 & $\begin{array}{l}\text { Planning } \\
\text { Organizing } \\
\text { Actuating } \\
\text { controlling }\end{array}$ & $\begin{array}{l}5.65 \\
20.56 \\
336.62 \\
41.41 \\
\end{array}$ & $\begin{array}{l}18,860,18 \\
5.182 .88 \\
316.56 \\
2,573.29 \\
\end{array}$ \\
\hline 3 & OBL & $\begin{array}{l}\text { Planning } \\
\text { Organizing } \\
\text { Actuating } \\
\text { controlling } \\
\end{array}$ & $\begin{array}{l}5.65 \\
74.53 \\
267.57 \\
43.61 \\
\end{array}$ & $\begin{array}{l}18,860,18 \\
1,429.76 \\
398.25 \\
2,443.48 \\
\end{array}$ \\
\hline 4 & IBL & $\begin{array}{l}\text { Planning } \\
\text { Organizing } \\
\text { Actuating } \\
\text { controlling } \\
\end{array}$ & $\begin{array}{l}7.15 \\
65.36 \\
243.48 \\
72.96 \\
\end{array}$ & $\begin{array}{l}14,903.50 \\
1,630.35 \\
437.65 \\
1,460.53 \\
\end{array}$ \\
\hline 5 & BASS & $\begin{array}{l}\text { Planning } \\
\text { Organizing } \\
\text { Actuating } \\
\text { controlling } \\
\end{array}$ & $\begin{array}{l}10,13 \\
87.44 \\
241.65 \\
51.49 \\
\end{array}$ & $\begin{array}{l}10,519.25 \\
1,218.66 \\
440.97 \\
2,069.53 \\
\end{array}$ \\
\hline \multicolumn{4}{|c|}{ Amount } & $109,677.92$ \\
\hline \multicolumn{5}{|c|}{ ASD } \\
\hline 1 & WDSM & $\begin{array}{l}\text { Planning } \\
\text { Organizing } \\
\text { Actuating } \\
\text { controlling } \\
\end{array}$ & $\begin{array}{l}5.15 \\
56.85 \\
237.38 \\
84.63 \\
\end{array}$ & $\begin{array}{l}20,691.26 \\
1,874.41 \\
448,90 \\
1,259.13 \\
\end{array}$ \\
\hline 2 & RPR & $\begin{array}{l}\text { Planning } \\
\text { Organizing } \\
\text { Actuating } \\
\text { controlling } \\
\end{array}$ & $\begin{array}{l}7.61 \\
75.98 \\
236.62 \\
66.25 \\
\end{array}$ & $\begin{array}{l}14.002 .63 \\
1,402.47 \\
450.34 \\
1,608.45 \\
\end{array}$ \\
\hline 3 & OCM & $\begin{array}{l}\text { Planning } \\
\text { Organizing } \\
\text { Actuating } \\
\text { controlling } \\
\end{array}$ & $\begin{array}{l}7.61 \\
70.47 \\
244.36 \\
62.39 \\
\end{array}$ & $\begin{array}{l}14.002 .63 \\
1,512.13 \\
436.08 \\
1,707.97 \\
\end{array}$ \\
\hline 4 & VVEM & $\begin{array}{l}\text { Planning } \\
\text { Organizing } \\
\text { Actuating } \\
\text { controlling } \\
\end{array}$ & $\begin{array}{l}5.05 \\
70.42 \\
256.65 \\
53.21 \\
\end{array}$ & $\begin{array}{l}21,100,99 \\
1,513.21 \\
415,20 \\
2002.63 \\
\end{array}$ \\
\hline 5 & COMPL & $\begin{array}{l}\text { Planning } \\
\text { Organizing } \\
\text { Actuating } \\
\text { controlling } \\
\end{array}$ & $\begin{array}{l}7.04 \\
80,80 \\
233.47 \\
62.01 \\
\end{array}$ & $\begin{array}{l}15136.36 \\
1,318.81 \\
456.42 \\
1,718.43 \\
\end{array}$ \\
\hline \multicolumn{4}{|c|}{ Amount } & $103,058.45$ \\
\hline
\end{tabular}


Helmi Alfiansyah et.al. Analysis of human resource needs through the workload of PT Telkom Indonesia (case study: government service division).

\begin{tabular}{|c|c|c|c|c|}
\hline \multicolumn{5}{|c|}{ Table 2 Continued... } \\
\hline & & & & \\
\hline 1 & SD & $\begin{array}{l}\text { Planning } \\
\text { Organizing } \\
\text { Actuating } \\
\text { controlling }\end{array}$ & $\begin{array}{l}8.35 \\
36,40 \\
251.87 \\
87.98 \\
\end{array}$ & $\begin{array}{l}12,761.68 \\
2,927.47 \\
423.08 \\
1,211.18 \\
\end{array}$ \\
\hline 2 & SDC & $\begin{array}{l}\text { Planning } \\
\text { Organizing } \\
\text { Actuating } \\
\text { controlling }\end{array}$ & $\begin{array}{l}6.15 \\
50.55 \\
264.67 \\
63.75 \\
\end{array}$ & $\begin{array}{l}17,326.83 \\
2,108.01 \\
402.61 \\
1,671.53 \\
\end{array}$ \\
\hline \multicolumn{4}{|c|}{ Amount } & $38,832.39$ \\
\hline \multicolumn{5}{|c|}{ GRS } \\
\hline 1 & Support & $\begin{array}{l}\text { Planning } \\
\text { Organizing } \\
\text { Actuating } \\
\text { controlling }\end{array}$ & $\begin{array}{l}7.35 \\
58.25 \\
245.43 \\
76.95 \\
\end{array}$ & $\begin{array}{l}14,497.96 \\
1,829.36 \\
434.18 \\
1,384.80 \\
\end{array}$ \\
\hline 2 & ATM & $\begin{array}{l}\text { Planning } \\
\text { Organizing } \\
\text { Actuating } \\
\text { controlling }\end{array}$ & $\begin{array}{l}10,15 \\
45.91 \\
220.77 \\
111.50 \\
\end{array}$ & $\begin{array}{l}10,498.52 \\
2,321.06 \\
482.67 \\
955,70 \\
\end{array}$ \\
\hline 3 & GDP & $\begin{array}{l}\text { Planning } \\
\text { Organizing } \\
\text { Actuating } \\
\text { controlling }\end{array}$ & $\begin{array}{l}10.75 \\
61.32 \\
255.74 \\
56.42 \\
\end{array}$ & $\begin{array}{l}9,912.56 \\
1,737.77 \\
416.67 \\
1,888,69 \\
\end{array}$ \\
\hline \multicolumn{4}{|c|}{ Amount } & $46,359.93$ \\
\hline \multicolumn{5}{|c|}{ SCD } \\
\hline 1 & EXPER & $\begin{array}{l}\text { Planning } \\
\text { Organizing } \\
\text { Actuating } \\
\text { controlling }\end{array}$ & $\begin{array}{l}10.98 \\
61.33 \\
238.43 \\
73.90 \\
\end{array}$ & $\begin{array}{l}9,704.92 \\
1,737.49 \\
446.92 \\
1,441.95\end{array}$ \\
\hline 2 & SMART & $\begin{array}{l}\text { Planning } \\
\text { Organizing } \\
\text { Actuating } \\
\text { controlling }\end{array}$ & $\begin{array}{l}15,16 \\
46.52 \\
268.05 \\
55.16 \\
\end{array}$ & $\begin{array}{l}7,029.02 \\
2,290.63 \\
397.54 \\
1,931.83 \\
\end{array}$ \\
\hline 3 & PLANNING & $\begin{array}{l}\text { Planning } \\
\text { Organizing } \\
\text { Actuating } \\
\text { controlling }\end{array}$ & $\begin{array}{l}10,12 \\
63.92 \\
211.52 \\
47.01 \\
\end{array}$ & $\begin{array}{l}10,529.64 \\
1,667.08 \\
503.78 \\
2,266.75 \\
\end{array}$ \\
\hline & unt & & & $39,947.56$ \\
\hline
\end{tabular}

\section{4) Setting allowance standards}

The size of the standard allowance for each slack factor can be seen in Table 3 .

Table 3 Calculation of Standard Allowance

\begin{tabular}{|c|c|c|c|c|c|c|}
\hline No & Category & Time & Frequency & Amount & Available Time & Allowance Standard \\
\hline \multicolumn{7}{|c|}{ PPS } \\
\hline 1 & Business Planning & 57.32 & 1776.00 & 101800.32 & 106560.00 & 0.96 \\
\hline 2 & Account Data Management & 60.20 & 1776.00 & 106915.20 & 106560.00 & 1.00 \\
\hline 3 & Secretariate and Resource Optimization & 20.09 & 1776.00 & 35679.84 & 106560.00 & 0.33 \\
\hline 4 & Revenue Assurance and Quality Management & 53.13 & 1776.00 & 94358.88 & 106560.00 & 0.89 \\
\hline 5 & Invoicing and Cash Collection & 45.98 & 1776.00 & 81660.48 & 106560.00 & 0.77 \\
\hline \multicolumn{6}{|c|}{ Amount } & 3.95 \\
\hline \multicolumn{7}{|c|}{ BDM } \\
\hline 1 & Legal Compliance 1 & 41.41 & 1776.00 & 73544.16 & 106560.00 & 0.69 \\
\hline 2 & Legal Compliance 2 & 41.41 & 1776.00 & 73544.16 & 106560.00 & 0.69 \\
\hline 3 & Outbound Logistics & 43.61 & 1776.00 & 77451.36 & 106560.00 & 0.73 \\
\hline 4 & Inbound Logistics & 72.96 & 1776.00 & 129576.96 & 106560.00 & 1.22 \\
\hline 5 & Bidding Administration Support & 51.49 & 1776.00 & 91446.24 & 106560.00 & 0.86 \\
\hline \multicolumn{6}{|c|}{ Amount } & 4.18 \\
\hline \multicolumn{7}{|c|}{ ASD } \\
\hline 1 & Wifi Deployment and Service Migration & 84.63 & 1776.00 & 150302.88 & 106560.00 & 1.41 \\
\hline 2 & Reconciliation and Performance Report & 21.12 & 1776.00 & 37509.12 & 106560.00 & 0.35 \\
\hline 3 & Order Connectivity Report & 17.38 & 1776.00 & 30866.88 & 106560.00 & 0.29 \\
\hline 4 & VVIP and Event Management Service & 53.21 & 1776.00 & 94500.96 & 106560.00 & 0.89 \\
\hline 5 & Complaint Handling & 62.01 & 1776.00 & 110129.76 & 106560.00 & 1.03 \\
\hline \multicolumn{6}{|c|}{ Amount } & 3.97 \\
\hline \multicolumn{7}{|c|}{ GSP } \\
\hline 1 & Solution Deployment & 87.98 & 1776.00 & 156252.48 & 106560.00 & 1.47 \\
\hline 2 & Solution Deployment and Capex & 63.75 & 1776.00 & 113220.00 & 106560.00 & 1.06 \\
\hline \multicolumn{6}{|c|}{ Amount } & 2.53 \\
\hline
\end{tabular}


Helmi Alfiansyah et.al. Analysis of human resource needs through the workload of PT Telkom Indonesia (case study: government service division).

\begin{tabular}{|c|c|c|c|c|c|c|}
\hline \multicolumn{7}{|c|}{ Table 2 Continued... } \\
\hline \multicolumn{7}{|c|}{ GRS } \\
\hline 1 & Government Relations Support & 58.50 & 1776.00 & 103896.00 & 106560.00 & 0.98 \\
\hline 2 & Account Team Management & 66.34 & 1776.00 & 117819.84 & 106560.00 & 1.11 \\
\hline 3 & Government Development Program & 56.42 & 1776.00 & 100201.92 & 106560.00 & 0.94 \\
\hline \multicolumn{6}{|c|}{ Amount } & 3.02 \\
\hline \multicolumn{7}{|c|}{ SCD } \\
\hline 1 & Smart City Experience & 51.50 & 1776.00 & 91464.00 & 106560.00 & 0.86 \\
\hline 2 & Smart City Solution Integration & 55.16 & 1776.00 & 97964.16 & 106560.00 & 0.92 \\
\hline 3 & Smart City Planning and Control & 106.44 & 1776.00 & 189037.44 & 106560.00 & 1.77 \\
\hline \multicolumn{6}{|c|}{ Amount } & 3.55 \\
\hline
\end{tabular}

\section{5) Calculation of HR needs per work unit}

Calculation of HR needs per work unit aims to obtain the number and type or category of HR per work unit according to the workload for one year (Helianty 2014). The calculation of the total HR needs can be seen in Table 4.

Table 4 Calculation of HR Needs per Work Unit

\begin{tabular}{|c|c|c|c|c|c|}
\hline No & Category & HR Needs & Allowance Standard & Number of Needs & Rounding \\
\hline \multicolumn{6}{|c|}{ PPS } \\
\hline 1 & Business Planning & 6.64 & 0.96 & 7.60 & 8.00 \\
\hline 2 & Account Data Management & 6.59 & 1.00 & 7.59 & 8.00 \\
\hline 3 & Secretariate and Resource Optimization & 6.46 & 0.33 & 6.79 & 7.00 \\
\hline 4 & Revenue Assurance and Quality Management & 6.69 & 0.89 & 7.57 & 8.00 \\
\hline 5 & Invoicing and Cash Collection & 6.48 & 0.77 & 7.24 & 8.00 \\
\hline & & & & & 39.00 \\
\hline \multicolumn{6}{|c|}{ BDM } \\
\hline 1 & Legal Compliance 1 & 6.74 & 0.69 & 7.43 & 7.00 \\
\hline 2 & Legal Compliance 2 & 6.74 & 0.69 & 7.43 & 7.00 \\
\hline 3 & Outbound Logistics & 6.52 & 0.73 & 7.25 & 7.00 \\
\hline 4 & Inbound Logistics & 6.48 & 1.22 & 7.70 & 8.00 \\
\hline 5 & Bidding Administration Support & 6.51 & 0.86 & 7.37 & 7.00 \\
\hline & & & & & 36.00 \\
\hline \multicolumn{6}{|c|}{ ASD } \\
\hline 1 & Wifi Deployment and Service Migration & 6.40 & 1.41 & 7.81 & 8.00 \\
\hline 2 & Reconciliation and Performance Report & 6.44 & 0.35 & 6.79 & 7.00 \\
\hline 3 & Order Connectivity Management & 6.41 & 0.29 & 6.70 & 7.00 \\
\hline 4 & VVIP and Event Management Service & 6.42 & 0.89 & 7.31 & 7.00 \\
\hline 5 & Complaint Handling & 6.39 & 1.03 & 7.42 & 7.00 \\
\hline & & & & & 36.00 \\
\hline \multicolumn{6}{|c|}{ GSP } \\
\hline 1 & Solution Deployment & 6.41 & 1.47 & 7.88 & 8.00 \\
\hline 2 & Solution Deployment and Capex & 6.42 & 1.06 & 7.48 & 7.00 \\
\hline \multirow{2}{*}{\multicolumn{2}{|c|}{ GRS }} & & & & 15.00 \\
\hline & & & & & \\
\hline 1 & Government Relations Support & 6.47 & 0.98 & 7.44 & 7.00 \\
\hline 2 & Account Team Management & 6.47 & 1.11 & 7.58 & 8.00 \\
\hline 3 & Government Development Program & 6.40 & 0.94 & 7.34 & 7.00 \\
\hline & & & & & 22.00 \\
\hline \multicolumn{2}{|c|}{ SCD } & & & & \\
\hline 1 & Smart City Experience & 6.41 & 0.86 & 7.27 & 7.00 \\
\hline 2 & Smart City Solution Integration & 6.41 & 0.92 & 7.33 & 7.00 \\
\hline 3 & Smart City Planning and Control & 5.54 & 0.77 & 6.32 & 7.00 \\
\hline & & & & & 21.00 \\
\hline
\end{tabular}

Based on the results of the calculation, it was found that the optimum manpower requirement in the PPS unit after rounding off was 39 employees, the BDM unit was 36 employees, the ASD unit was 36 employees, the GSP unit was 15 employees, the GRS unit was 22 employees, and the SCD unit was 21 employees. At the time of observation, the number of employees available in the Government
Service Division was 85 employees consisting of 22 PPS units, 18 BDM units, 17 ASD units, 7 GSP units, 13 GRS units, and the SCD unit as many as 8 employees.

\section{Calculation of Employee Needs Based on the WISN Method}

After conducting research in the field using a work sampling formula and interviewing in the form of a questionnaire 
to the management and the unit that is the source of information in the research, then with the steps written in the WISN user manual (WHO 2010) to get the results of calculating the number of human resources required. Employee needs based on WISN calculations can be seen in Table 5 .

Table 5 Employee needs based on WISN calculations

\begin{tabular}{|l|l|l|l|l|}
\hline No & Category & Labor Available & Optimum Needs & Advantages or Disadvantages \\
\hline 1 & PPS & 22 & 39.00 & -17.00 \\
\hline 2 & BDM & 18 & 36.00 & -18.00 \\
\hline 3 & ASD & 17 & 36.00 & -19.00 \\
\hline 4 & GSP & 7 & 15.00 & -8.00 \\
\hline 5 & GRS & 13 & 22.00 & -9.00 \\
\hline 6 & SCD & 8 & 21.00 & -13.00 \\
\hline
\end{tabular}

The analysis in Table 5 shows that the Government Service Division as a whole still requires manpower, where the PPS unit requires 17 employees, the BDM unit requires 18 employees, the ASD unit requires 19 employees, the GSP unit requires 8 employees, the GRS unit requires 9 employees, and the SCD unit requires 13 employees. So it can be concluded that the company is advised to conduct recruitment to meet the labor shortage.

Table 6 Calculation of WISN . Ratio

\begin{tabular}{|l|l|l|l|l|l|}
\hline No & Category & Labor Available & Optimum Needs & Advantages or Disadvantages & WISN Rasio Ratio \\
\hline 1 & PPS & 22 & 39 & -17.00 & 0.56 \\
\hline 2 & BDM & 18 & 36 & -18.00 & 0.50 \\
\hline 3 & ASD & 17 & 36 & -19.00 & 0.47 \\
\hline 4 & GSP & 7 & 15 & -8.00 & 0.47 \\
\hline 5 & GRS & 13 & 22 & -9.00 & 0.59 \\
\hline 6 & SCD & 8 & 21 & -13.00 & 0.38 \\
\hline
\end{tabular}

The WISN user manual (WHO 2010) explains that if the work value ratio is one, the number of workers is in accordance with the demands of the workload or is sufficient. The results of the WISN ratio analysis in the DGS division show that the WISN ratio of the six units in the DGS division is below 1.0, so it can be concluded that the DGS Division's workforce is not in accordance with the existing workload because the workload is greater than the available workforce.

\section{Managerial Implications}

This research is expected to have implications for the Government Service Division to pay attention to the workload and the optimum number of employees, so that employees can provide maximum results in accordance with the targets set by the company. This is because this study provides an overview and results that excessive workload and the number of employees who are not optimal can affect work processes and work results. The following are managerial implications that can be used as input for sub-units in the Government Service Division to achieve maximum results.

1) The Government Service Division can pay attention to the workload and the optimum number of employees it has, so that employees can provide maximum results in accordance with the targets set by the company. The Government Service Division implements an increase in achievement every year, so that the workload of each employee also increases every year. This phenomenon must be observed by the management where each employee has a different workload capacity. The diversity of employee capacities will be an obstacle for the company to achieve its annual target if it does not procure manpower in each sub-unit of work.

2) There is supervision on the recruitment of workers because there is a possibility that there is a mismatch between the needs of the organization and the competence of the workforce. Placement of workers without doing calculations 
will result in workers not being able to work effectively and efficiently, this is because the workforce must make adjustments to new things so that it hampers the development of sub units.

3) The account team management sub-unit becomes the main priority in adding workers, this is because the sub-unit is the only sub-unit responsible for training and developing other sub-units. When the account team management sub-unit has reached the optimum point of human resource needs, the sub-unit will be able to work more effectively and efficiently to meet the training and development needs of other sub-units.

4) There needs to be a reward given to the workforce whose function is to increase work motivation and work ethic so that the workforce increases the productivity of the Government Service Division.

5) The handling of labor must be followed up quickly but gradually so as not to cause new problems beyond the need for manpower.

\section{CONCLUSION}

1. The availability of the Government Service Division workforce for the Planning Performance and Support unit is 22 people, for the Bidding and Management unit is 18 people, for the Assurance and Delivery unit is 17 people, for the Government Solution and Partnership unit is seven people, for the Government Relations Service unit is 17 people. 13 people, and eight people for the Smart City Development unit.

2. The calculation of the needs obtained based on the WISN formula shows that the optimum number of needs from the Government Service Division for the Planning Performance and Support unit is 39 people, Bidding and Management is 36 people, for the Assurance and Delivery unit is 36 people, for the Government Solution and Partnership unit is 15 people. 22 people, for the Government Relations Service unit, and
21 people for the Smart City Development unit.

3. To achieve an effective and efficient workload, it is necessary to increase the number of workers, for the Planning Performance and Support unit it is necessary to add 17 people, for the Bidding and Management unit it is necessary to add 18 people, for the Assurance and Delivery unit it is necessary to add as many as 19 people, for the Government Solution and Partnership unit it is necessary to add eight people, for the Government Relations Service unit it is necessary to add nine people, and for the Smart City Development unit it is necessary to add 13 people.

\section{Acknowledgement: None}

\section{Conflict of Interest: None}

\section{Source of Funding: None}

\section{REFERENCES}

1. Brown KL, Pagel C, Pienaar A, Utley M. The relationship between workload and medical staffing levels in a paediatric cardiac intensive care unit. Intensive Care Med. 2011 Feb;37(2):326-33. doi: 10.1007/s00134-010-2085-0. Epub 2010 Dec 2. PMID: 21125216.

2. Cascio, Wayne F. 2007. Managing Human Resources. Colorado (US): McGraw-Hill.

3. Castro MMAJ, Stetz. 2007. The impact of deactivation uncertainty, workload, and organization constraints on reverse psychological well-being and turnover intentions. Military Medicine. 172:576-580.

4. Dessler, G. 2004. Human Resource Management. Jakarta (ID): Index.

5. Durham S, Merritt J, Sorrell J. 2007. Implementing a new faculty workload formula. Nursing Education Perspective. 28: 184-189.

6. Handoko, TH 2001. Personnel Management and Human Resources. Yogyakarta.(ID): BPFE Yogyakarta.

7. Hasibuan M. 2001. Human Resource Management Non-Secular Approach. 
Surakarta (ID): Muhammadiyah University Press.

8. Hasibuan M. 2005. Human Resource Management. Jakarta (ID): Earth Literacy

9. Hasibuan M. 2013. Human Resource Management. Jakarta (ID): Earth Literacy

10. Hasibuan M. 2006. Human Resource Management. Jakarta (ID): Earth Literacy.

11. Helianty Y. 2014. Needs Analysis of Number of Employees Based on Workload Analysis. Integra Design. 4(1): 250-258.

12. Ilyas Y. 2011. Hospital HR Planning, Theory, Methods and Formulas. 3rd Ed. Depok (ID): FKM UI.

13. Mangkuprawira, S. 2003. Strategic Human Resource Management. Jakarta (ID): PT. Ghalia Indonesia.

14. Musau P, Nyongesa P, Shikule A, Birech E, Kirui D, Njenga M, Mbiti D, Bett A, Lagat L, Killu K. 2008. Workload indicators of staffing need method in determining optimal staffing levels at MOI teaching and referral hospital. East African Medical Journal. 86(6): 9-232.

15. Nazmin E, Kroeger A, Sidiqui A, Sundar S, et al. 2013. Human resource assessment for scaling up VL active case detection in Bangladesh, India and Nepal. Tropical Medicine and International Health. 18: 734742.

16. Notoadmojo S. 2009. Human Resource Development. Jakarta (ID): Rineka Cipta.

17. Pregiwati LA. 2007. Analysis of the need for middle-level fisheries manpower to meet the capture fisheries industry in Indonesia [thesis]. Bogor (ID): IPB.
18. Rahardjo M. 2008. Analysis of the implementation of training in increasing work productivity of sales employees at PT. $\mathrm{X}$ in Jakarta. Management Journal. 12(2): 176-190

19. Rivai, HV 2006. Human Resource Management for Companies, From Theory to Practice. Jakarta (ID): PT. Rajagrafindo Persada.

20. Rivai, HV and EJ Sagala. 2009. Human Resource Management for Companies From Theory to Practice. Jakarta (ID): Rajawali Press.

21. Shivam S, Ray RN, Dasgupta S, Bhattadiaryya KD, Misra RN, Roy S, Saha I. 2014. Nursing personnel planning for rural hospitals in Burdwan District, West Bengal, India, using workload indicators of staffing needs. J health PCPLL Nutr. 32: 658-664.

22. Tibby SM, Correa JW, Murdoch LA. 2004. Adverse events in a pediatric intensive care unit: relationship to workload, skill mix and staff supervision. Intensive Care Med. 30:1160-1166.

23. WHO. 2010. Workload Indicators of Staffing Need. Geneva (CH): WHO Press.

How to cite this article: Helmi Alfiansyah, M. Syamsul Maarif, Nimmi Zulbainarni. Analysis of human resource needs through the workload of PT Telkom Indonesia (case study: government service division). International Journal of Research and Review. 2021; 8(12): 473-487. DOI: https://doi.org/10.52403/ijrr. 20211259 